\title{
UNA NUEVA \\ INTERPRETACIÓN DE \\ EL NACIMIENTO \\ DE LA TRAGEDIA
}

Mónica Salcido Macías*

RESUMEN: En el marco de las interpretaciones de White, Porter y Sloterdijk, el presente artículo amplía la discusión acerca de El nacimiento de la tragedia, de Nietzsche, como una obra que carece de tope interpretativo definitivo, identificando esta característica con el corazón de la filosofía crítica y escéptica del pensador alemán. Por medio de una metareflexión, se postulan nuevas claves de interpretación de la reinvención nietzscheana de la Antigüedad griega y su vinculación crítica con la filología clásica.

\section{শ্ల}

ABSTRACT: In the context of the works by White, Porter and Sloterdijk, this article furthers the discussion concerning Nietzsche's work, The Birth of Tragedy, namely its lack of definitive interpretative boundaries, which lies at the heart of his critical and skeptical philosophy. We propose new ways of interpreting the Nietzchian reinvention of Greek antiquity and its critic link to classical philology.

PALABRAS CLAVE: historia, filosofía, sabiduría trágica, Nietzsche.

KEYWORDS: history, philosophy, Nietzsche, tragedy.

RECEPCIÓN: 11 de marzo de 2008

APROBACIÓN: 22 de mayo de 2008

* Instituto Tecnológico y de Estudios Superiores de Monterrey, Ciudad de México. 
La reproducción total o parcial de este artículo se podrá hacer si el ITAM otorga la autorización previamente por escrito. 


\section{UNA NUEVA \\ INTERPRETACIÓN DE \\ EL NACIMIENTO \\ DE LA TRAGEDIA}

La frase de Nietzsche "no hay hechos, sólo interpretaciones" es una clave para entender su interpretación del mundo griego. Leer El nacimiento de la tragedia sin el fundamento teórico de que todas las que llamamos "verdades" son perversiones de un impulso estético original, propuesto por el filósofo en su opúsculo Sobre verdad y mentira en sentido extramoral, puede llevarnos a una lectura superficial que queda atrapada en los mitos interpretativos que rodean, después de una larga historia de recepción, esta obra. La opera prima de Nietzsche necesita nuevas lecturas, pues el mismo texto se presta a una constante reinterpretación desde el momento en que logramos captar en él una propuesta fundamental: el estudio del pasado, la historia, como puesta en escena de representaciones ficticias, es un relato cuyo contenido estructural profundo es de naturaleza poéticolingüística y que no expresa "hechos en estado bruto" sino sólo perspectivas que dependen de intenciones, ideologías y hasta de elecciones éticas.

Hayden White ${ }^{1}$, uno de los intérpretes más originales de la postura de Nietzsche ante la historia, postula que el acercamiento al pasado es un campo de batalla en el que las múltiples perspectivas se baten a duelo sin alcanzar, finalmente, una respuesta definitiva: existen tantas verdades sobre el pasado como existen perspectivas individuales, por lo que no hay una naturaleza "real" de los hechos ni una única visión valedera del pasado histórico. White ha atisbado singularmente que

${ }^{1}$ Hayden White, Metahistoria. La imaginación histórica en la Europa del siglo XIX, 1992, México, F.C.E., tr. Stella Mastrangelo. 
cuando Nietzsche arma su discurso histórico sobre el pasado clásico en realidad está haciendo una meta-reflexión que, en el marco de una afirmación trágica de la existencia, se despliega en varios niveles: como reflexión sobre la estructura del pensamiento histórico y el papel que el pasado debe jugar en el presente; sobre el carácter ficticio de todo conocimiento; sobre la capacidad humana de crearse ilusiones que le permitan seguir viviendo, y todo ello dirigido hacia una filosofía de la cultura en la que la modernidad reflexiona sobre sí misma y se enfrenta, teniendo a la Antigüedad como espejo de autoconfrontación, a sus fallos. En este sentido, la Grecia de Nietzsche, una reelaboración que definitivamente rebasa los límites de la investigación filológica, resultó amenazante para la colmena de la academia clasicista: al poner en jaque sus convicciones objetivistas y plantear que, ya que los hombres contemplan la historia conforme a sus motivos, no hay una Grecia única y verdadera, echó por la borda los usuales cánones interpretativos para transformar el pasado clásico de un objeto diseccionable, observado "desinteresadamente", en una metáfora que se transfigura en los distintos proyectos de quien a ella se acerca y que, en vez de ser un fin en sí misma, es un medio de autoafirmación y de autoconstrucción. Así comprendida, la reconstrucción nietzscheana de la Antigüedad clásica se nos muestra como expresión de una filosofía propia que promueve una nueva narrativa que posterga la objetividad del discurso histórico como tarea de la actividad filológica. Siendo así, la pregunta sobre si su interpretación del helenismo es correcta o no se convierte en una cuestión secundaria. La sustancia filosófica del texto radica, como señala Sloterdijk, ${ }^{2}$ en una postura trágica y perpectivística que reconoce su discurso como efímero, como puesta en escena de una idealización que en el juego de relatos que conforma las diversas vertientes del neohelenismo alemán, se inicia como obra de un filósofo, y no sólo un filólogo, que, desconfiado del relato clasicista, intenta rescatar a los griegos de la atmósfera conservadora de la academia alemana y las formas del poder en que aquél se sostiene. Así, como filólogo, filósofo y, diría yo, artista, Nietzsche

${ }^{2}$ Peter Sloterdijk, El pensador en escena. El materialismo de Nietzsche, 2000, Valencia, Pre-Textos, tr. Germán Cano. 
concibió una dramaturgia que busca reescenificar la Antigüedad griega a partir de otros puntos de vista y de una activa meditación sobre el presente y sus problemas, desplegando con ello un discurso refractario a la visión anticuaria del canon académico, y transformando el pasado clásico de un objeto diseccionable en un escalpelo de crítica cultural y, por qué no, también en un producto artístico.

Partiendo de la idea de que la historia siempre enuncia verdades nuevas, Nietzsche reescribe el pasado desde una concepción filosófica de Grecia, cuyo estudio no tiene como intención básica la reconstrucción de "cómo realmente sucedieron los hechos" sino una exhortación a retomar la concepción trágica de la vida con la que los griegos se enfrentaron al cosmos, y con ello, promover una forma de vida en la que la "Antigüedad real", a la que buscaban acercarse los estudios filológicos del siglo XIX, es sustituida por una Antigüedad ideal, comprendida como fuerza libre, creadora y transformadora: “¡Recuperar la visión antigua del mundo! ¡La moira reina realmente sobre todas las cosas, los dioses representantes de poderes reales! ¡Volverse antiguo!"3

A lo largo de su trabajo intelectual sobre la Antigüedad clásica, proyecto que es en sí una meta reflexión, Nietzsche se encarga de dar al pasado nuevos sentidos, de establecer conexiones alternas que rechazan los aspectos sistemáticos y absolutistas de la historia, plegando con ello un tradicional sistema de interpretación a una nueva voluntad. Así, en el marco de una vertiente heterodoxa de la interpretación clasicista, nuestro filósofo teje otra red de ilusiones mediante las cuales reescribe el pasado griego proveyendo nuevos contextos, ensayando nuevas posibilidades que reivindican para el sentido histórico la conciencia de la finitud, no sólo de la vida, sino de toda interpretación. En este contexto El nacimiento de la tragedia es un texto que se despliega en varios niveles, que rebasa, sin abandonarlo del todo, el interés filológico, y cuyo estilo particular es expresión neta de su contenido: una interpretación de la Grecia trágica que se vierte en un texto, pero un texto que quiere ser helénico, politeísta y pagano, que no "superheleniza", que afirma la pluralidad de

${ }^{3}$ Friedrich Nietzsche, "Fragmentos póstumos inéditos", en "Nietzsche, 125 años", ECO, Revista de la Cultura de Occidente, tomo XIX/5-6-7, sept. -oct.-nov., Bogotá, 1969, p. 472. 
verdades y que propone una visión naturalista de la vida donde, al tiempo que la verdad se muestra, se enmascara. En una evocación actualizada del espíritu helénico -al cual desde ahora llamaré helenidad-Nietzsche toma decisiones radicales respecto a su relación con el material histórico, sometido esta vez a una experiencia reeducadora y revolucionaria que se debate contra una forma de existencia dogmatizada y, en el relato de la historia, contra el peso brutal de la tradición o los profesionales del sentido. Con El nacimiento de la tragedia afirma haber iniciado su proyecto de transvaloración, el propio texto nos exige una lectura desde la superación del concepto de verdad y un ejercicio del perspectivismo, es decir, "el arte de ver con múltiples ojos una sola cosa". ${ }^{4}$ Ejercitar el perspectivismo nos permite apreciar que tanto en la opera prima como en los llamados "escritos filológicos", Nietzsche ha dejado de hablar como un investigador del pasado clásico para transformarse en un "mitólogo de la historia", como lo llama Sloterdijk, un narrador que construye una interpretación del pasado que no intenta relatar "cómo realmente sucedieron los hechos", sino que parte de un terreno epistemológico en el que nuestro filósofo propone a la intimidad ficcional de todo conocimiento y a la verdad como una hueste de metáforas y metonimias. Así, tomando el opúsculo Sobre verdad y mentira en sentido extramoral como punto de partida de mi interpretación de El nacimiento de la tragedia, propongo que los escritos tempranos de éste filólogo del futuro deben ser leídos como escenificación de una postura filosófico-hermenéutica para la cual "no hay hechos, sólo interpretaciones".

La reinvención nietzscheana de Grecia apela a un uso sofisticado y táctico de las ideas, en cuya verdad Nietzsche no podía creer de forma simple porque su interpretación no dependía del ansia de saber, que él tanto criticó a la historiografía y, ni qué decirlo, a la filología académica a la que él mismo perteneció. El nacimiento de la tragedia es, desde mi interpretación, una obra esencialmente metafórica sobre el fenómeno de la tragedia que enfrenta al lector consigo mismo a través de párrafos que sugieren una lectura no lineal, poniéndole al tanto de sí

${ }^{4}$ F. Nietzsche, La genealogía de la moral, tratado tercero, §12, 1997, México, Alianza, tr. Andrés Sánchez Pascual, p. 139. 
misma como una construcción ilusoria que combate el fallo cultural con el que el hambre historicista aniquiló el mito, como bien nos refiere Nietzsche en el parágrafo 23:

Quien quiera examinarse a sí mismo con todo rigor para saber hasta qué punto es él afín al verdadero oyente estético, o si pertenece a la comunidad de los hombres socrático-críticos, limítese a preguntarse sinceramente cuál es el sentimiento con el que acoge el milagro representado en el escenario: si acaso siente ofendido su sentido histórico, el cual está orientado hacia la causalidad psicológica rigurosa, o si con una benévola concesión, por así decirlo, admite el milagro como un fenómeno comprensible para la infancia, pero que a él se le ha vuelto extraño, o si experimenta alguna otra cosa. Ateniéndose a esto se podrá medir, en efecto, hasta qué punto está él capacitado para comprender el mito, imagen compendiada del mito, y que, en cuanto abreviatura de la apariencia, no puede prescindir del milagro. ${ }^{5}$

Al impugnar las artimañas dogmáticas de la consistencia y la argumentación, El nacimiento de la tragedia es un ejemplo de la obra de arte trágica que Nietzsche proyecta al pasado y que, como todo arte trágico, dice Hayden White, "es a la vez realistamente ilusionista y destructor creativo de sus propias ilusiones". ${ }^{6} \mathrm{Si}$ interpretamos este escrito a la luz de la lectura de James I. Porter ${ }^{7}$ de esta obra como un proyecto mitológico, es posible desarmar las interpretaciones que ven en ella un libro esencialmente "dionisiaco" y "anticlásico": sus sentidos posibles dependen siempre de un principio de selección y su calidad míticoartística la lleva a desatarse varias maneras de las "ligaduras de lo escrito". Ahora bien, lo que quiero decir no es que Nietzsche haya escrito "mentiras” en torno al mundo clásico, como lo acusó Wilamowitz, sino que, como he comentado antes, su reinvención del mundo griego

${ }^{5}$ F. Nietzsche, El nacimiento de la tragedia, 1994, Madrid, Alianza, tr. Andrés Sánchez Pascual, p. 179.

${ }^{6}$ Hayden White, op. cit., p. 322-3.

${ }^{7}$ Véase James I. Porter, The Invention of Dionysus: an Essay on The Birth of Tragedy, 2000, Stanford, Stanford University Press. 
es ella misma dramatización de una postura filosófica, esencialmente trágica, que abarca distintos modos de la certeza y en donde la propuesta de la ilusoriedad de lo real promueve la entrada en escena de una inteligencia constructiva, donde la inversión de la expresión "mentira" ataca el moralismo del imperativo de verdad, pudiéndose hablar, en adelante, de la belleza y el encanto de "lo falso". Por otra parte, tampoco podemos acusar al texto de ser simplemente "retórico": no lo es de forma simplista porque recordemos que para Nietzsche la realidad es ella misma retórica y que, como acto del lenguaje, está condicionada histórica y culturalmente. Para decirlo con Porter, Nietzsche despliega en su propio texto una narración falsa y estructuras equívocas de sentido que apuntan hacia una visión trágica de la vida, que se sabe a sí misma ilusoria al tiempo que reflexiona sobre la estructura ficcional de todo conocimiento; de ahí su "disonancia semántica”, la cual, según Paul de Man, ${ }^{8}$ no es lingüística ni retórica sino antropológica, como Nietzsche señala en el parágrafo 18 de El nacimiento de la tragedia: "Si pudiéramos imaginarnos una encarnación de la disonancia - ¿y qué otra cosa es el ser humano?-, esa disonancia necesitaría, para poder vivir, una ilusión magnífica que extendiese un velo de belleza sobre su esencia propia". 9

Ahora bien, si no podemos confiar en la lectura nietzscheana del pasado clásico como verdad histórica - porque la misma nos lleva a desarmar su "objetividad" con un entramado filosófico que dota al texto de una lógica auto-negativa-, ¿qué sentido tiene El nacimiento de la tragedia? ¿Con miras a qué fue escrito? Esta primera obra, ejercicio de la concepción de la historia que Nietzsche desarrollará en su segunda intempestiva, obedece a un esfuerzo de redescubrimiento del pasado que se dirige a un ejercicio de autoconocimiento, trazando al mismo tiempo una imagen de grandes exigencias histórico-filosóficas, donde Grecia representa el plan para una nueva vida basándose en la más antigua visión del mundo. Y no sólo eso: es una valoración de la existencia y

\footnotetext{
${ }^{8}$ Véase Paul de Man, Alegorías de la lectura, 1990, Barcelona, Lumen, tr. Enrique Lynch.

${ }^{9}$ F. Nietzsche, op. cit., § 25, p. 190.
} 
un acceder al enigma del ser desde el fenómeno de la disonancia. La Antigüedad griega es, en Nietzsche, una metáfora que nos habla del arte de atravesar las máscaras para una nueva valoración de la vida, de un pensamiento cuya fuerza creadora e instintiva recupera el pathos trágico, la conciencia que señala a la aniquilación como ley inexorable y a toda unidad como siempre cambiante, inmersa en un proceso de lucha infatigable que carece de finalidad. Y es que para Nietzsche asomarse al mundo antiguo en busca de un paradigma que permita transformar la cultura del hombre moderno, no puede responder a la necesidad insaciable -historicista- de adquirir conocimientos para extender las redes del saber. Con Nietzsche, la interpretación de Grecia se acerca más a un ejercicio filosófico que de erudición; su clasicismo nos habla no de un pasado paradigmático sino de una fuerza renovable, un carácter, una manifestación de la voluntad que busca ser libre. Aquí reflexión, intelecto claro y objetividad, se entienden como desarticulación del dogma, y en sus rasgos más oscuros, quizá los más tentadores, como profundidad y pathos, como capacidad para digerir el hecho de que el mundo es un enigma inalcanzable y aún nosotros mismos lo somos, sujetos a la ley de cambio, de alternancia que rige al universo. Desde esta perspectiva, en la que la helenidad exige dejar de favorecer el factor lógico-racional del pensamiento para permitir la participación de una subjetividad profundamente anclada en las propias pasiones, la filología del futuro, que es ya El nacimiento de la tragedia, promueve la reunión de pensamiento y vida, la recuperación del genio filosófico que desarticula verdades universales y reconoce el carácter ficticio de los ideales, preguntándose en su "escenario helenístico-psicodramático", ${ }^{10}$ como lo llama Sloterdijk, qué tanta verdad somos capaces de soportar si por verdad entendemos esa hueste de metáforas y metonimias que señalan hacia el vacío sobre el que se sostienen.

La filología del futuro es un desmantelamiento epistemológico para el cual la conciencia es un fundamento sin fundamento; así, El nacimiento de la tragedia es un libro que, al hablar del fenómeno griego de la tragedia como una intoxicación cultural que busca darle forma al caos,

${ }^{10}$ Véase Peter Sloterdijk, op. cit., p. 79. 
reconoce para sí mismo esta misma intoxicación, postulando ya de entrada su permanente exposición a la bancarrota; al cuestionar todo orden formulado con pretensión de verdad, su discurso se autodescubre como un simulacro sospechoso que incorpora a Apolo como una forma de entender y practicar la filosofía. Si "todo lo que es profundo ama la máscara", bajo la "máscara del especialista filosófico de los abismos", ${ }^{11}$ haciendo preguntas radicales sobre el pasado clásico ante las que cesa toda teoría concebida en términos de "verdad" y "objetividad", el principal propósito de Nietzsche es acabar con noúmenos, sustancias y agentes espirituales, poniendo de manifiesto las ilusiones producidas por lo que, a fin de cuentas, no es más que un hábito lingüístico, postulando al mismo tiempo una voluntad de apariencia que se reconoce a sí misma como tal y que, como conciencia metafórica, propugna una actitud de asunción consciente de las ilusiones. Será a través de los griegos que Nietzsche sostendrá esta postura, ubicando a la base del espíritu trágico de Esquilo y Sófocles un juego de significados que, según él, no estaba más allá del puro juego musical de la fuerza apolínea creadora de imágenes y la explosión dionisiaca de las mismas, teniendo como fundamento, metafísicamente proyectado, el terrible texto básico del absurdo cósmico sobre el cual los griegos reescribieron, con una determinante voluntad de superficie y en nombre de la vida, una multiplicidad de sentidos posibles. Por ello, dice Hayden White.

Para Nietzsche, los griegos habían sido los primeros en apreciar hasta qué punto la vida humana dependía de las fuerzas mitopoéticas del hombre, su capacidad de soñar un sueño de salud y belleza frente a su propia aniquilación inminente. La cultura griega en su edad de oro se había desarrollado, para él, con plena conciencia de las bases ficticias sobre las cuales se apoyaba. Él comparaba esa cultura con un templo erigido sobre pilares hundidos en el fango viscoso del lago de Venecia; ofrecía una ilusión de permanencia y autosuficiencia, y por eso permitía que la vida continuara, pero coloreaba todo acto realizado dentro del

${ }^{11}$ Ibidem. 
edificio de una conciencia controlada del carácter esencialmente tenue de la vida, de su aterradora finitud. ${ }^{12}$

La cultura griega no era para Nietzsche una simple huída del caos primario, pues en el arte trágico los griegos hallaron un modo de recordarse a sí mismos que la cultura humana es, en el mejor de los casos, una realización frágil sostenida en el vacío del que provienen todas las cosas y al cual regresan. La realidad como esfuerzo cultural era tomada como un complejo juego de ilusiones que se reemplazan unas a otras, donde la vida creadora era posible mediante una conciencia de la interdependencia entre el caos y la forma. Es posible interpretar que el Nietzsche filólogo asumió su lectura de esta postura filosófica griega para su propia reconstrucción de la Antigüedad; así pues, Apolo y Dionisos aparecerán en Nietzsche como metáforas de un movimiento cósmico y cultural, como proyecciones cuyo sentido va mucho más allá de ser una caracterización de la esencia del mundo y del fenómeno ático de la tragedia: más bien forman parte de un pensamiento que asume, piensa Sloterdijk, una "termodinámica de la ilusión" que derriba los ídolos del monotonoteísmo pero que conserva el principio de la energía creadora de ilusiones: ${ }^{13}$ al tiempo que Nietzsche destruye una imagen de la Antigüedad, la de la "noble sencillez y serena grandeza", transmitida por Winckelmann, construye otra, la Grecia trágica, agónica, antihumanista; al tiempo que fluidifica interpretaciones congeladas, se nutre de la acción de mentir en un juego con las máscaras antiguas, cuyas evoluciones se dan en el reconocimiento de la mentira como existencialmente irremediable: "en este sentido - dice Nietzsche- tengo derecho a considerarme el primer filósofo trágico - es decir, la máxima antítesis y el máximo antípoda de un filósofo pesimista. Antes de mí no

${ }^{12}$ H. White, op.cit., p. 322.

${ }^{13}$ P. Sloterdijk, op.cit., p. 83-4: "El pensamiento nietzscheano se adentra en un horizonte al que corresponde una termodinámica de la ilusión; se orienta, por así decirlo, según un 'principio de conservación de la energía creadora de ilusiones'. Se derrumban los ídolos pero la fuerza que idolatra permanece constante; los ideales se congelan, pero el ardor que idealiza sigue errando sin objeto y ávido; ha finalizado la situación de estar engañado, pero los depósitos de los que se nutre la acción de mentir, no están agotados." 
existe esa transposición de lo dionisiaco a un pathos filosófico". ${ }^{14}$ Fue en la tragedia griega, y con ello hablamos ya de la propia interpretación de Nietzsche, donde el filólogo encontró un espacio para afirmar la vida del individuo libre que, como cómplice del cataclismo de los sueños sobre los que se basa la existencia humana, crea nuevas ilusiones en los intersticios existentes entre los sistemas institucionalizados de la verdad.

Para Nietzsche, el pesimismo griego, que no es el mismo que el de Schopenhauer ni, como dirá más tarde en Ecce Homo, el suyo, es el único caso en la historia que es paralelo a su experiencia interior: "El pesimismo es la consecuencia del conocimiento de la absoluta ilogicidad del orden del mundo"15 y es parte medular de esa verdad trágica que Nietzsche busca reincorporar al pensamiento, una verdad casi inatrapable, huidiza, que, sin embargo, es lo suficientemente fuerte como para desmantelar las ilusiones que han fundamentado a Occidente. La verdad trágica se aproxima más a la globalidad de la vida, a lo eternamente recurrente: el caos, el dolor, la tragedia existencial y los misterios del ser. La Grecia trágica de El nacimiento de la tragedia-esa Grecia dionisiaco-apolínea, agónica- es una metáfora propia de la ilustración nietzscheana porque tiene como punto esencial la valentía, y con ella me refiero no sólo a la de aquel que se enfrenta a la verdad institucionalizada de la colmena académica sino a aquella que, como psicología filosófica, hace referencia al teatro de los enunciados, abandonados por la verdad. Me parece que lo que Nietzsche reconocerá como "verdad trágica" en la Antigüedad clásica sugiere aplicar ese mismo parámetro de verdad a su propio texto, apostando por ello, en su obra más conocida sobre el mundo griego, por un rango de incertidumbre, por un desasimiento de la voluntad de verdad propia de Occidente, la cual prefiere, dice el filósofo, "un puñado de 'certeza' a toda una carreta de hermosas posibilidades". ${ }^{16}$

${ }^{14}$ F. Nietzsche, "El nacimiento de la tragedia", en Ecce homo, 2000, Madrid, Alianza, tr. Andrés Sánchez Pascual, p. 78.

${ }^{15}$ F. Nietzsche, (KGB 3.3.74), citado por Joshua Foa Dienstag, "Nietzsche's Dionysian Pessimism", en American Political Science, University of Virginia, vol. 95, núm. 4, diciembre, 2001. La traducción es mía.

${ }^{16}$ F. Nietzsche, "De los prejuicios de los filósofos", § 10 en Más allá del bien y del mal, 1985, México, Alianza, tr. Andrés Sánchez Pascual, p. 29. 
Frente al optimismo teórico, Nietzsche se pregunta cuánta verdad somos capaces de soportar cuando la verdad ya no funciona estando al servicio de un control intelectual de la existencia, sino como constatación del fondo caótico e irracional de esta misma. Con la máscara del filólogo, Nietzsche establece un vínculo personalísimo con el teórico trágico del conocimiento que pone frente a sí a la vida como un todo que, por su multiplicidad, rechaza toda tendencia monoteísta. La interpretación de la tragedia se ha convertido en un ejercicio creativo, en donde el pasado se transforma en una imagen representativa mediante la cual el filósofo propone una nueva ética del pensamiento que rechaza los embates absolutistas de la metafísica cristiana, que, como los griegos, dice "sí a la vida incluso en sus problemas más extraños y duros"; 17 una forma de pensar que recupera lo que él identifica como la primera experiencia filosófica: la unión entre vida y conocimiento, entre sentidos y razón.

El nacimiento de la tragedia como producto de una nueva ética del pensamiento supone metáforas cargadas de una subversión dionisiaca que redescubre el mundo a partir de otra posición respecto al ser y la verdad, que surge no como opción alterna a la metafísica, sino como el inicio de una transmutación de los valores en dirección a la afirmación de lo efímero, de la recuperación del "sentido de la tierra", la afirmación del absurdo y del sentido que la vida tiene sólo ante sí misma. Es con esta opera prima que surgieron las argumentaciones de Zaratustra en contra de las significaciones profundas, de las verdades superiores, de la preexistencia del sentido con respecto a la expresión; aquí, Nietzsche se decide por la imagen y por el humo, escoge el mundo olímpico griego como mundo artístico para demorarse en el juego de los signos: Apolo, Dionisos, Esquilo, Sófocles, Sócrates, Heráclito... todos ellos pseudónimos de la superficie, del mundo sustitutorio que es el mundo verdadero, elementos clave de una filosofía natural y antiteológica que se opone a todo idealismo y principio teológico, aceptando al mundo contradictorio de la physis y a la conciencia humana como instancias provisionales,

${ }^{17}$ F. Nietzsche, "Lo que yo debo a los antiguos", en Crepúsculo de los ídolos, 2000, Madrid, Alianza, tr. Andrés Sánchez Pascual, p. 143. 
como meros accidentes evolutivos. Me parece que la filología del futuro -en la que "se ha convertido en filosofía lo que era filología"-18 es un intento de reinstauración de la filosofía en el pensamiento histórico, el cual sólo es útil a la vida cuando enfatiza el problema de la existencia, es decir, cuando tiene, digámoslo así, un "impulso clásico" que reconoce la ambivalencia como característica del ser y la insuficiencia del intelecto humano para ahondar en las profundidades del cosmos. De este modo, en la interpretación nietzscheana del pasado clásico, lo que podemos llamar una "historia filosófica", y más aún una "filosofía histórica", guarda una estrecha relación con la conciencia ilusoria: consciente del devenir, sabe que todo presupuesto de orden es una construcción intelectual, posible entre muchas y siempre proclive a naufragar.

Nietzsche busca el licenciamiento del horizonte intelectual y ético de Occidente para dar entrada a una nueva y original filosofía, que sólo reconoce como precedente la filosofía presocrática, una filosofía antisocrática, más aún, antiplatónica. Será Heráclito quien resumirá con mayor esplendor este heroísmo intelectual en una concepción del cosmos como devenir y lucha. El filósofo de Éfeso será un alma gemela para el pensador alemán, porque, como él, quiere asumir en su propia filosofía la finitud y el carácter transitorio y ambivalente de lo real; lo transitorio y ambivalente diría yo de su propia obra sobre la tragedia, la cual quiere expresarse sin proporcionar una veritas aeterna, puesto que el ser es él mismo disonante, inalcanzable para el discurso, nunca agotado por la palabra: "Lo uno, lo único, lo sabio, no quiere y [sin embargo] quiere ser llamado con el nombre de Zeus". ${ }^{19}$ El pensamiento, como el mundo, es móvil, no aprehende, sino que señala; reproduciendo la tensión que ordena al cosmos, se contradice, se transforma. La misma contradicción del mundo se ve reflejada en la filosofía de Nietzsche aunque, como señala Porter, exista la tendencia a ignorar las contradicciones de la exposición nietzscheana. La obra filológica de Nietzsche es tan

${ }^{18}$ Véase F. Nietzsche, Homero y la filología clásica, 1995, Madrid, Ediciones Clásicas, tr. Luis Jiménez Moreno.

${ }^{19}$ Heráclito, fg. 32. (Rodolfo Mondolfo, Heráclito: textos y problemas de su interpretación, 1966, México, siglo XXI, p. 35). 
compleja que no resulta válido reducir su concepción del pasado a una sola fórmula: es "anticlásica", es "dionisiaca". Carece de una consistencia radical: es más bien dispar, tensa, ambigua y, algunas veces, hasta contradictoria, factores en los que radica la dificultad de su interpretación. El relato nietzscheano de la Antigüedad griega es como el resto de su obra: nos exige abrirnos a las eventualidades del texto, recrearlo mediante una visión propia sin un intento de atrapar su complejidad o, lo que es lo mismo, tratando de escapar del laberinto del pensamiento del propio Nietzsche. Así como Nietzsche cuestionó la "objetividad" como un camino hacia el conocimiento del mundo antiguo, tampoco podemos hablar de la objetividad del propio Nietzsche ni de nuestra propia lectura: consciente o inconscientemente, lo que buscamos precondiciona lo que encontramos. Para leer a Nietzsche no hay que atenerse a la literalidad del texto; él mismo vivió el carácter oposicional de su pensamiento y lo expuso, marcando con ello, de manera definitiva, su estilo como una amalgama compleja que muchas veces surge con el signo de la incompatibilidad. La paradoja y la ambivalencia son en el texto nietzscheano sobre la tragedia una forma de exponer su propia postura filosófica, por eso no podemos leerlo desde la tradición de la unicidad conceptual: el texto incorpora radicalmente la filosofía a la investigación del pasado griego como un ejercicio de desenmascaramiento, pero no para mostrar una verdad más auténtica.

Como ejercicio de filosofía trágica, El nacimiento de la tragedia pone en acción la metáfora del juego heraclítea del cosmos con su imagen del ir y venir entre Apolo y Dionisos, ilusiones con las que se da nombre al intercambio entre el caos y la forma donde aparecen los significados, las verdades, los dioses y hasta los abismos que la razón no alcanza a penetrar. El juego nos habla, en la temprana filosofía del pensador alemán, de un lenguaje en ausencia de la verdad, de un entrenamiento en la semántica del abandono de Dios, de una estimulante catástrofe que afirma la vida y el sufrimiento teniendo ante sí el arte y la ilusión, perspectivas que el propio Nietzsche asumió como inherentes a "la filosofía en la época trágica de los griegos". Juego del mundo, metáfora con la cual Nietzsche entreteje la filosofía con el arte y que, llevada a su 
postura frente a la filología académica, sirve para restringir el impulso de conocimiento y reconocer en el intelecto un productor de imágenes que resultan siempre antropomórficas.

El antagonismo entre Apolo -condensación en imágenes, claridad, solidez- y Dioniso - cambio, ardiente vivir, éxtasis- es una interpretación filosófica concreta del mundo que se abre paso sin utilizar el lenguaje usual, sistemático y conceptual de la filosofía. Siendo una teoría que surge de un "ojo artístico" que busca un nuevo comienzo del pensamiento occidental, es rica en términos, expresiones, metáforas e imágenes que expresan que el mundo es una y otra cosa a la vez, que es caos y voluntad de forma, unidad primordial y realidad escindida; metáforas que sirven "como imagen representativa" en lugar de concepto, ${ }^{20}$ y que forman parte de El nacimiento de la tragedia como proyecto mitológico. Apolo y Dioniso enfrentados en constante lucha son acontecimiento cósmico, instintos de la naturaleza, pero sobre todo formas y palabras donde la profundidad detrás de la apariencia es ella misma otro pliegue de la apariencia, otra superficie que aparece como lo insondable. Dioniso, el fondo íntimo del mundo, "el corazón de la naturaleza”, unidad primordial que se despedaza para crear individuos, es, en gran medida, una invención de Apolo, el hacedor del bello sueño que sueña la esencia del mundo. Uno y otro como estructuras ontológico-metafísicas aparecen en El nacimiento de la tragedia de forma imaginaria, a partir de una voluntad de ilusión que parece ser aún más profunda y connatural que la voluntad de verdad. En tanto que parte de una empresa ficcional, "Apolo" y "Dioniso", apariencia y voluntad, sólo tienen una existencia a posteriori, así como la-cosa-en-sí en oposición a la apariencia forma parte de nuestra constitución y nuestra psicología: son una apariencia más procedente de la ilimitada profusión de imágenes que la mente genera y a las que da forma idealizándolas de acuerdo a deseos subjetivos y hábitos adqui-

${ }^{20}$ F. Nietzsche, El nacimiento de la tragedia, p. 83: "Por una peculiar debilidad de la inteligencia moderna, nosotros nos inclinamos a representarnos el fenómeno estético primordial de una forma demasiado complicada y abstracta. Para el poeta auténtico la metáfora no es una figura retórica, sino una imagen sucedánea que flota realmente ante él, en lugar de un concepto". 
ridos colectivamente. Aunque se ha planteado infinidad de veces que el Dioniso nietzscheano es expresión del fundamento del mundo, anterior al principio de individuación que es la apariencia, la metáfora es un reforzamiento de una teoría del simulacro que pone a El Nacimiento de la tragedia bajo sospecha filosófica. Dioniso, al igual que su reino, sólo existe imaginado por una visión; por ello, cabe preguntarse, como lo hace Nietzsche, en qué medida lo dionisiaco es una invención de lo apolíneo ${ }^{21}$ y, más aún, asegurar que el dionisismo de Nietzsche es un fenómeno moderno que el filósofo ha proyectado en el pasado. Apolo y Dioniso son en la obra nietzscheana como los dioses epicúreos: simulacros, concepción humana, símbolos éticos, antropomorfismos que evidencian su finitud y que, ya que son concebidos como principios cosmológicos, en la misma idea de su eternidad, refuerzan la idea de que lo eterno es quizás la concepción más antropomórfica de todas. Cuando Nietzsche dice de Apolo y Dioniso: "esos nombres se los tomamos en préstamo a los griegos", ${ }^{22}$ nos da una visión del mundo griego que es libremente ilusoria y que se reconoce como tal, pues nada prohíbe que el mundo de los dioses sea sólo una bella apariencia, mero fantasma o imagen del sueño. Proyectemos al texto nietzscheano su propia hipótesis: "Los griegos, que soñaron a sus divinidades, debieron tener un oscuro sentimiento de que éstos eran hijos de su invención, por lo que sus mitos contenían en sí mismos su propia negación escéptica, expresada en el presentimiento de un crepúsculo de los dioses". ${ }^{23}$ Los dioses griegos pertenecen, pues, al reino de un conocimiento negado: el ordenamiento ilusorio del mundo y la permanente exposición al desastre de este mismo orden.

Según Sloterdijk, la lectura de El nacimiento de la tragedia debe, pues, ser cautelosa, pues "la preeminencia temática de lo dionisiaco

${ }^{21}$ F. Nietzsche, op. cit., p. 96-7: "Mas, para servirnos de la terminología de Platón, acerca de las figuras trágicas de la escena helénica habría que hablar más o menos de este modo: el único Dioniso verdaderamente real aparece con una pluralidad de figuras, con la máscara de un héroe que lucha y, por así decirlo, aparece preso en la red de una voluntad individual [...] y el que llegue a aparecer con tal precisión y claridad épicas es el efecto del Apolo intérprete de sueños, que mediante aquella apariencia simbólica le da al coro una interpretación de su estado dionisiaco".

${ }^{22}$ F. Nietzsche, ibid., p. 40.

${ }^{23}$ Véase ibid., § 9. 
no puede minusvalorar la supremacía dramatúrgica de lo apolíneo”. ${ }^{24}$ Si podemos hablar de esta obra como dionisiaca es porque, continúa este intérprete, en Nietzsche lo dionisiaco significa pagano, anticristiano, inmoralista, trágico... pero en general es un manifiesto apolíneo porque está a favor de una "precensura dórica" que alude a un principio selectivo e individualista a partir del cual el filósofo ha armado su propia narrativa sobre el pasado clásico. Apolo como apariencia y Dioniso como voluntad son asunciones que nos dejan ver que toda profundidad metafísica se revela a sí misma como superficie y que su fundamento descansa sólo en la posibilidad de ser concebida. El movimiento entre Apolo y Dioniso hace pues referencia al teatro de la ilusión sobre el que se escenifica todo movimiento cultural; nos habla de la distancia protectora frente a lo insoportable y es clave de la nueva teoría trágica del conocimiento que postula que "tenemos al arte para no perecer a causa de la verdad”: ¿cuál verdad? La de que no hay verdades, que todo enunciado se apoya en sí mismo, que "Apolo" y "Dioniso" son, asimismo, enunciados vacíos. En este sentido, me parece fundamental recalcar que, si para Nietzsche la filosofía de Heráclito es como un terremoto bajo nuestros pies, su propio pensamiento es también un terremoto filosófico frente al cual la mascarada Apolo-Dioniso pierde importancia en la medida en que es sólo el punto de partida de una concepción trágica de la vida que afirma el sufrimiento teniendo ante sí el arte y la ilusión.

Si los grandes conceptos son el último humo de la realidad que se evapora, ${ }^{25}$ Apolo y Dioniso deben ser leídos en El nacimiento de la tragedia como indicadores de un uso sofisticado de las ideas en las cuales Nietzsche no cree más que como parte de un ejercicio de la ficcionalidad. Aunque Dioniso es una mera idea a la que Apolo, idea a su vez de la apariencia, proporciona la arquitectura sobre la cual se proyecta su imagen, el dionisismo como asunción es parte medular de una filosofía que recurre a la redención del sinsentido del mundo no por medio de escapismos metafísicos sino de una voluntad de superficie que se niega

${ }^{24}$ P. Sloterdijk, op. cit., p. 66.

${ }^{25}$ F. Nietzsche, “La 'razón’ en la filosofía”, en Crepúsculo de los ídolos, op. cit., p. 53. 
a tomar las cosas de un modo profundo. Dioniso, pues, es el signo de la pasión, no de la cosa en sí misma; él existe en el nivel de un ideal representativo forjado en el marco de una filología centáurica - puesto que es una mezcla de filosofía, arte y ciencia- que postula a la filosofía como una forma de arte que fusiona no sólo a Apolo y a Dioniso, sino a la sabiduría trágica con la ciencia jovial, tarea que no se limita a El nacimiento de la tragedia, sino que, me parece, se fragua en toda la obra nietzscheana como proyecto de remetaforización del mundo. Así, la irrupción dionisiaca del discurso en El nacimiento de la tragedia nos habla no de una empresa teórica sino dramática, que enuncia abiertamente los aspectos insoportables de la vida y que es de netas consecuencias para la cultura teórico-moral. Si consideramos esta obra como un texto que imita los movimientos de un contorsionista, no es sólo el concepto de filología el que pierde su linealidad: la filosofía también sufre modificaciones casi corporales, donde la verdad cambia de lugar y se hace parte de un juego de sustituciones, de "puesta entre paréntesis", como expresa Sloterdijk. Con la interpretación dionisiaca de Grecia, Nietzsche "descubre" esa otra Grecia en la que el pensamiento reflexivo crea mundos en concomitancia con aquellos creados por el arte, donde sin literatura, sin relato, no hay verdad.

El filósofo es contemplativo como el artista creador, pasivo como el hombre de religión, causal como el científico: intenta que todos los sonidos del mundo resuenen en él y que esta consonancia se traduzca en conceptos, inflamándose en el macrocosmos y, en este sentido, considerándose a sí mismo con gran circunspección; al igual que el espectador o el poeta dramático que, transformándose, mantienen la serenidad proyectando en palabras esta transformación. El filósofo vierte el pensamiento dialéctico sobre sí como si se bañara en una cascada. ${ }^{26}$

Pesimismo y obra de arte trágica, fusión entre sabiduría trágica y ciencia jovial, destrucción de figuras que limitan la vida e instinto constructor de metáforas que dan liviandad al absurdo son la auténtica dupli-

${ }^{26}$ F. Nietzsche, Los filósofos preplatónicos, 2003, Madrid, Trotta, tr. Francesc Ballesteros, p. 24. 
cidad contenida en El nacimiento de la tragedia, obra filosófico-musical que entona el preludio de un saber trágico que expone abiertamente el sufrimiento como un ingrediente fundamental de la vida, enfrentándolo como parte de un juego cuya fuerza superior es capaz de convertir en alegría y ligereza la seriedad y el peso, permitiendo el acceso a una concepción no metafísica del cosmos, que afirma la inocencia del devenir, el ciclo auto regulador del cambio en el que el fuego se apaga y se enciende según medidas, donde todo se somete a la misma fatalidad y donde la constante transformación no permite perspectivas eternas.

El nacimiento de la tragedia no es sólo una agitación antisocrática que denuncia críticamente una filosofía teorética y no artística: sus figuras -Apolo, Dioniso, Heráclito, Sócrates, Esquilo y Sófocles-son aporías narrativas que forman parte de la ficción nietzscheana en la que se fragmentan las identidades como símbolo de la heterogeneidad de todos los materiales clásicos que la filología de etiqueta ${ }^{27}$ trata de resolver en una "clasicalidad" esencial. En este sentido, creo que desde el punto de vista del centauro arte-ciencia-filosofía que Nietzsche mismo propone, la obra plantea una corriente postmetafísica de pensamiento donde el redescubrimiento de la helenidad significa la recuperación del genio filosófico trágico para posibilitar un futuro más lúcido, una nueva experiencia de lo real, libre de los límites impuestos por la moral, la lógica y la razón, ampliando el concepto de pensamiento a la experiencia originaria del sinsentido y la liberación de los fines, teniendo como ejemplo cultural al pueblo griego, cuya visión del mundo es para nuestro filósofo una vieja verdad despreciada en la que, ante el trasfondo aparencial de lo dionisiaco, la banalidad brilla de un modo abismal.

${ }^{27}$ Véase Manuel Crespillo, La mirada trágica (Exégesis sobre la idea de extravio trágico), 1994, Málaga, Hybris. 